\title{
CHEMICAL AND PHYSICAL CHARACTERISTICS OF SHALLOW GROUND WATERS IN NORTHERN MICHIGAN BOGS, SWAMPS, AND FENS ${ }^{1}$
}

\author{
Christa R. Schwintzer ${ }^{2,3}$ and Thomas J. Tomberlin ${ }^{4}$ \\ The University of Michigan Biological Station," Pellston, Michigan 49769, \\ Harvard University, Harvard Forest, Petersham, Massachusetts 01366, and \\ Department of Statistics, ${ }^{4}$ Harvard University, Cambridge, Massachusetts 02138
}

\section{A B S T R A C T}

Fifteen chemical and physical characteristics were examined in samples of shallow ground water taken in midsummer at $15-30 \mathrm{~cm}$ below the surface in six bogs, 15 swamps, and six fens. The wetland types were identified on the basis of their vegetation. Three groups of covarying water characteristics were identified by factor analysis. Factor $\mathrm{I}$ included $\mathrm{Ca}, \mathrm{Mg}, \mathrm{Si}, \mathrm{pH}$, alkalinity, conductivity and to a much lesser extent $\mathrm{Na}$, and reflects the degree of telluric water influence in the wetland. Factor 2 included reactive-P, total- $\mathrm{P}, \mathrm{NH}_{3}-\mathrm{N}$, and to a lesser extent $K$, and consists of elements that primarily enter interstitial water via organic matter decomposition. Factor 3 included $\mathrm{Na}, \mathrm{Cl}$, and to a much lesser extent $\mathrm{K}$.

The wetlands formed two distinct groups with respect to water chemistry: weakly minerotrophic ( $\mathrm{pH} 3.8-4.3)$ including all bogs and moderately to strongly minerotrophic ( $\mathrm{pH} 5.5-7.4)$ including all swamps and fens. The bogs had very low values for Factor 1 characteristics and moderate values for the remaining characteristics. The swamps and fens had moderate to high values for Factor 1 characteristics and showed considerable overlap in this respect. The fens had consistently low values for Factor 2 characteristics but overlapped with some swamps which also had low Factor 2 scores. Failure to completely separate the vegetationally very distinct swamps and fens from each other on the basis of their physical and chemical water characteristics indicates that another factor, probably water level regime, is of major importance in determining their vegetation type.

NoRTHERN Michigan bogs, conifer swamps, and fens differ strongly in floristics, species density, proportion of evergreen species, role of symbiotic nitrogen fixing species, and role of Sphagnum spp. (Schwintzer, 1981). Considerable evidence indicates that the ionic balance and cation content of wetland waters strongly influence wetland floristics and vegetation type (DuRietz, 1954; Sjörs, 1961; Gorham, 1967; Heinselman, 1970; Moore and Bellamy, 1974; Pietsch, 1976; and others). Based on water chemistry two main classes of wetland are recognized: 1) ombrotrophic; and 2) minerotrophic. Ombrotrophic wetlands are dependent on precipitation for water and minerals. Consequently their waters are highly deficient in telluric mineral ions (ions leached from mineral soils and bedrock by percolating water)

\footnotetext{
${ }^{1}$ Received for publication 6 June 1981; revision accepted 9 August 1981.

We thank Kent $\mathrm{O}$. Jones for extensive help in the field, Jerry Krausse for water chemistry analyses, Harold F. Hemond for helpful comments on the manuscript, and Frances $O^{\prime}$ Brien for typing the manuscript. This work was supported by NSF-RANN Grant No. AEN72-03483 to the University of Michigan Biological Station and by Harvard Forest and represents a contribution from the University of Michigan Biological Station.

${ }^{3}$ Present address: Dept. Botany and Plant Pathology, University of Maine, Orono, ME 04469.
}

and have low metal-ion saturation of the peat and low $\mathrm{pH}$. In contrast at least some telluric water enters minerotrophic wetlands. Here metal-ion saturation of the peat and $\mathrm{pH}$ depend on the amount of telluric water entering the wetland and the nature of the underlying strata in the region.

Little is known about shallow ground waters in northern Michigan wetlands and wetlands in other parts of the Laurentian Mixed Forest ecoregion (Bailey, 1976). The available information is limited to relatively complete descriptions of a bog in northern Michigan (Schwintzer, 1978a) and a fen in central Michigan (Richardson et al., 1978); and partial descriptions of shallow ground water in a variety of northern Wisconsin wetlands (Wilde and Randall, 1951) and northern Minnesota peatlands (Heinselman, 1970).

The present study examines shallow ground waters in or near the rooting zone in bogs, swamps and fens in northern Michigan to determine: 1) the nature of the waters found in the wetlands of this region; and 2) the extent of linkage between characteristics of shallow ground waters and wetland vegetation type. Five macronutrients (N, P, K, Ca, and $\mathrm{Mg}$ ) and other ions as well as $\mathrm{pH}$, alkalinity, conductivity, and color were measured in bogs, 
swamps, and fens. Bogs and fens were not further differentiated while the swamps were divided into conifer, hardwood, and thicket swamp because they are the most extensive wetland formation in the region.

The terms bog, swamp, and fen have been variously defined over the years. The present study follows the wetland classification and nomenclature proposed by Jeglum, Boissonneau and Haavisto (1974) for northern Ontario.

Nomenclature of the vascular plants follows Fernald (1950).

STUdy AREA-The wetlands included in this study are located in Emmet and Cheboygan counties in the northern tip of the Lower Peninsula of Michigan. This area is located in the Northern Hardwoods Forest section of the Laurentian Mixed Forest (Bailey, 1976) and is north of the transition (=tension) zone which separates the mixed conifer hardwood forest of the north from the deciduous forest in the south in Minnesota, Wisconsin, and Lower Michigan (Curtis, 1959; Kapp, 1978). The bedrock consists of dolomites and limestones but most of the surface is covered by glacial deposits and outcrops are rare (Dorr and Eschman, 1970; Alfred, Hyde and Larson, 1973).

The region has a warm continental climate (Bailey, 1976) with wet and dry periods up to several years in length which result in fluctuating water tables. Periods of high water occur at intervals of approximately ten years in Lake Michigan-Huron (U.S., D.C., NOAANational Ocean Survey) and in the Indian River watershed, which includes a portion of the study area (USDI, GS; Schwintzer, 1978a). During the summers of 1974 and 1975 water levels were high throughout the region, as indicated by runoff from the Indian River watershed and water levels in two bogs. Mid-July, water levels in Bryant's Bog were high from 1972 until 1977 (Schwintzer, 1979). Similar observations were made in Inverness Mud Lake Bog.

The region has extensive wetlands which include excellent examples of bog, swamp, fen, and marsh. Wetlands, as identified on U.S. Geological Survey topographic maps, occupy approximately $9 \%\left(109 \mathrm{~km}^{2}\right)$ and $15 \%\left(308 \mathrm{~km}^{2}\right)$ of the land areas of Emmet and Cheboygan counties, respectively. The vegetation of the northern Michigan wetlands closely fits the descriptions of the wetland types given by Jeglum et al. (1974) with the exception of hardwood swamps where red maple (Acer rubrum) or silver maple (Acer saccharinum) are leading dominants at some Michigan sites, but not in northern Ontario.
Most open bogs in the area are leather-leaf (Chamaedaphne calyculata) low shrub bogs. Three of the four sites examined were dominated by leather-leaf and Carex oligosperma. Treed bogs are relatively rare in the area. The two included were shrub-rich bogs dominated by black spruce (Picea mariana) and leatherleaf.

Conifer swamps constitute a large fraction of the total wetland area in the region. All sites examined were strongly dominated by white cedar (Thuja occidentalis). The vegetation of four of the six conifer swamps and of all six bogs has been described in detail elsewhere (Schwintzer, 1981). Hardwood swamps are much less common than conifer swamps. All of the sites studied contained varying amounts of silver maple, red maple, black ash (Fraxinus nigra), balsam poplar (Populus balsamea), quaking aspen (Populus tremuloides), white birch (Betula papyrifera), white cedar, tamarack (Larix laricina) and occasional other trees. Maples were dominant or codominant at all sites. Thicket swamps occupy relatively restricted areas and alder thicket is the most common type. All four sites examined were dominated by speckled alder (Alnus rugosa) and located along or near streams.

Fens are located primarily along streams and at the edges of lakes. All fens examined were low shrub fens and five were dominated by sweet gale (Myrica gale), Carex lasiocarpa and Carex aquatilis. The vegetation of five of the six sites has been described in detail elsewhere (Schwintzer, 1978b).

MATERIALS AND METHODS-Water sampling and analysis-Water samples were collected at 27 wetland sites at a depth of 15 to $30 \mathrm{~cm}$ below the peat surface. Each site was sampled on 1 day during July or early August in 1974 or 1975. In addition one site of each wetland type was sampled during both summers to determine year-to-year variation. The second year's samples were taken at the same points, which had been marked with wooden stakes, as the first year's.

The points at which individual samples were taken in each wetland were selected visually to represent the extent of variability at the site as judged by the vegetation. Three points were sampled in most wetlands but four were sampled in some. At each sample point a well was made by driving a piece of stove pipe with a diameter of $15 \mathrm{~cm}$ into the ground to a depth of $30 \mathrm{~cm}$, the peat inside the pipe was removed and the pipe was pulled up to a depth of $15 \mathrm{~cm}$ permitting water to enter from the sides of the well between 15 and $30 \mathrm{~cm}$. Significant con- 
tamination of the sample by waters from above $15 \mathrm{~cm}$ is unlikely because no surface waters were present and the pipe fit tightly within its hole. Water was pumped from the well with a hand vacuum pump until it was clear of most suspended particles. Duplicate samples were then taken by pumping from below the surface of the water. Samples were collected for analysis for: 1) alkalinity, conductivity, $\mathrm{pH}$, and color; and 2) dissolved chemicals. The samples for dissolved chemicals were collected in polyethylene bottles which were immediately placed on ice.

Alkalinity, conductivity, $\mathrm{pH}$, and color were measured in the laboratory within 8 hours of sample collection. Total alkalinity was determined by a potentiometric titration to an end point of pH 4.5 (APHA, 1971: Method 102). The $\mathrm{pH}$ was measured with a Beckman Model $\mathrm{H} 5 \mathrm{pH}$ meter. Conductivity was measured with an Industrial Instruments Model RC 16B2 conductivity bridge (APHA, 1971: Method 154). Apparent color was determined on undiluted samples at their original $\mathrm{pH}$ with a Hach Model DR-EL/2 test kit using the platinum-cobalt standard scale (APHA, 1971: Method 118).

Concentrations of the remaining chemical parameters were determined in the water chemistry laboratory at the University of Michigan Biological Station. All samples were passed through $0.45-\mu \mathrm{m}$ pore size celluloseacetate filters within 8 hours of collection, and stored in polyethylene bottles in a freezer for no more than 6 months before analysis. Calcium, $\mathrm{Mg}, \mathrm{K}$, and $\mathrm{Na}$ were determined with a Perkin-Elmer Model 305 atomic absorption spectrophotometer under standard conditions (Perkin-Elmer, 1973), except for calcium, where $\mathrm{La}$ and $\mathrm{HCl}$ were added to both samples and standard solutions to give final concentrations of $0.25 \%(\mathrm{w} / \mathrm{v}) \mathrm{La}$ and $5 \%(\mathrm{v} / \mathrm{v}) \mathrm{HCl}($ PerkinElmer, 1973. EN-4). Ammonia-nitrogen, $\left(\mathrm{NO}_{2}\right.$ $+\mathrm{NO}_{3}$ )-N, Si, reactive-P, total-P, and $\mathrm{Cl}$ were determined with a Technicon Auto Analyzer II using the following method (Technicon, 1973): $\mathrm{NH}_{3}-\mathrm{N}$ (Berthelot reaction), $\left(\mathrm{NO}_{2}+\right.$ $\mathrm{NO}_{3}$ )-N (copper cadmium reduction method), $\mathrm{Si}$ (molybdenum blue method), reactive-P (phospho-molybdenum blue method), and $\mathrm{Cl}$ (ferric thiocyanate method). Total-P was measured as reactive-P after digestion with $5 \%$ potassium persulfate (Menzel and Corwin, 1965).

Colored organic compounds present in brown-stained wetland waters interfered with all of the colorimetric tests except for total-P where the digestion procedure rendered the solution clear. The effect of the interference was corrected for by determining the absorbance in a blank for the particular brown-stained water of interest and subtracting it from the absorbance of the sample. The brown-stained water blank included all reagents added to the sample except one or more of the reagents necessary for color development. Distilled water was added as needed to maintain the appropriate dilution factors. Only reagents that did not change the $\mathrm{pH}$ were excluded because the absorbance of brown-stained water changes with $\mathrm{pH}$. The following chemicals and reagents were excluded from the brown-stained water blanks: $\mathrm{NH}_{3}-\mathrm{N}$ (sodium hypochlorite), $\left(\mathrm{NO}_{2}+\right.$ $\mathrm{NO}_{3}$ )-N (sulfanilamide and $\mathrm{N}$-1-naphylethylenediamine dihydrochloride), Si (abscorbic acid), reactive- $\mathrm{P}$ (ascorbic acid), and $\mathrm{Cl}$ (mercuric thiocyanate and ferric ammonium sulfate).

Statistical analysis-Multivariate differences between pairs of wetland types were examined with Mahalanobis $\mathrm{D}^{2}$ statistics (BMPD7M revised November 1978: Dixon and Brown, 1977) using mean values for each of the eleven characteristics listed in Table 3 for each of the 26 sites with complete data. Four characteristics were omitted from this analysis because measurements were not available for several sites (conductivity, apparent color), the parameter was not directly related to water chemistry (temperature) or it showed strong evidence of year-to-year variation $\left(\mathrm{NO}_{2}+\right.$ $\mathrm{NO}_{3}$ )-N. Logs of values were used for $\mathrm{Ca}, \mathrm{Mg}$, $\mathrm{Si}$, reactive-P, and total-P to reduce heteroscedasticity.

Linear combinations of covarying water characteristics were identified by factor analysis (BMPD4M revised November 1978: Dixon and Brown, 1977). The factors were extracted by principal components analysis of the correlation matrix, the number of factors was limited to the number of eigenvalues greater than 1.000 (three in the case of these wetland data), orthogonal rotation by varimax was performed with gamma $=1.0000$, and Kaiser's normalization was used. Site means and $\log$ transformation of the same characteristics were used in this analysis as in the preceding analysis.

RESULTS-Midsummer values of most shallow ground water characteristics examined varied little from 1974 to 1975 in all five wetland types. The data are available from ASIS/NAPS as described in Table 1. The mean difference between 1974 and 1975 values for individual sample points was small for all water characteristics and statistically significant differences $(P \leqslant 0.05)$ between years were found for only three characteristics: $\mathrm{K},\left(\mathrm{NO}_{2}+\mathrm{NO}_{3}\right)-\mathrm{N}$, and temperature. Consequently, values for sites 
TABLE 1. Chemical and physical characteristics of shallow ground water in five wetland types in northern Lower Michigan. Values are mean \pm S.D. Intertype differences were tested by one-way analysis of variance and the Student-Newman-Keuls test (Sokal and Rohlf, 1969). Types not followed by the same letter are significantly different $(P<0.05)$

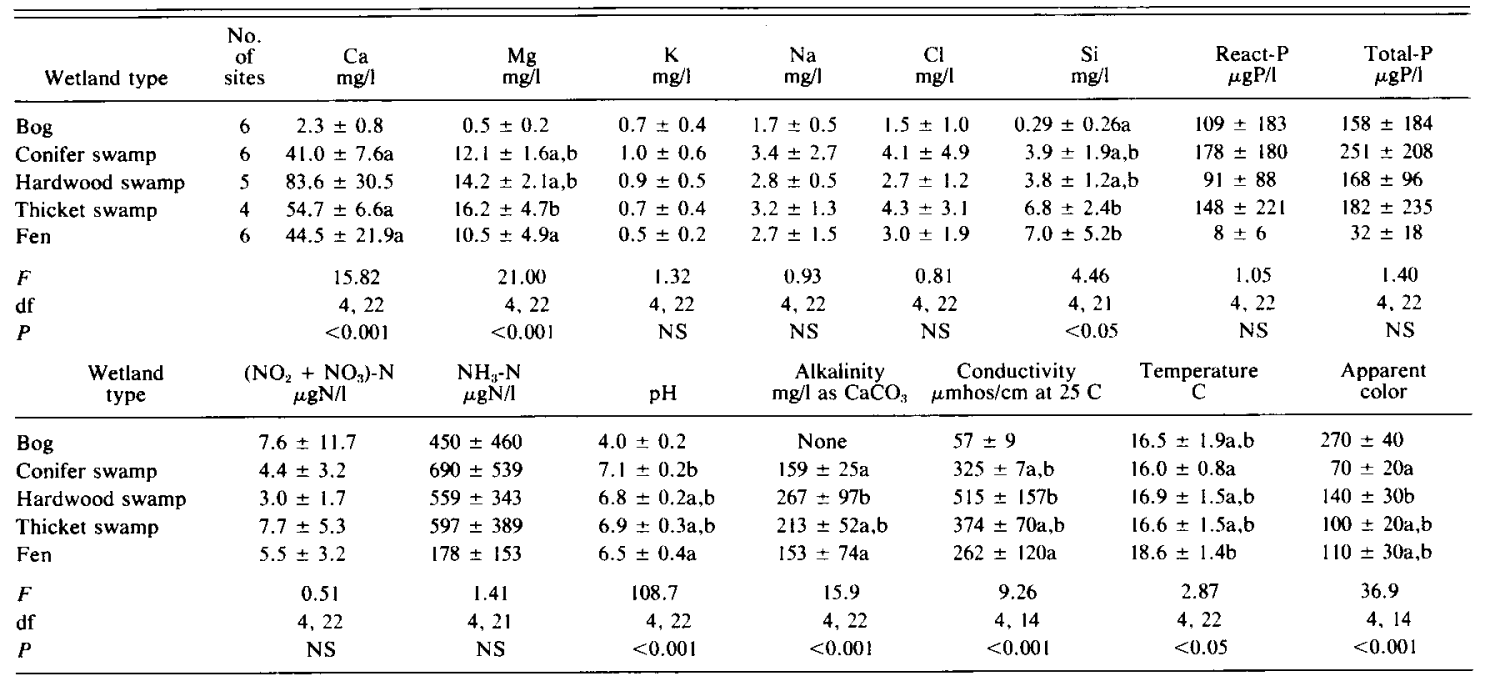

* Data, including location, sampling dates and values for individual water characteristics for all 27 sites examined as well as year-to-year differences at selected sites, has been deposited with the National Auxiliary Publication Service. See NAPS document \# 03979 for 13 pages of supplementary material. Order from ASIS/NAPS, Microfiche Publications, P.O. Box 3513, Grand Central Station, New York 10163. Remit in advance $\$ 4.00$ for microfiche copy or for photocopy, $\$ 7.75$ up to 20 pages plus $\$ .30$ for each additional page. All orders must be prepaid.

examined in 1974 and 1975 were pooled for data analysis.

Mean values for several water characteristics varied widely from one wetland type to another, whereas others had a more limited range of values (Table 1). Characteristics with a wide range included $\mathrm{Ca}, \mathrm{Mg}, \mathrm{Si}, \mathrm{pH}$, alkalinity, conductivity, reactive-P, and total-P. Characteristics with a small range of values included $\mathrm{K}, \mathrm{Na}, \mathrm{Cl}$, and temperature.

The data in Table 1 also show that the bogs differ significantly $(P<0.05)$ from the swamps and fens in having low values for $\mathrm{Ca}, \mathrm{Mg}, \mathrm{pH}$, alkalinity and conductivity, and high apparent color. In addition some of the swamps differ

TABLE 2. Multivariate F-matrix for shallow ground waters from five northern Michigan wetland types. All eleven water characteristics listed in Table 4 are included. Degrees of freedom $=11,11$

\begin{tabular}{lcccc}
\hline \hline & Bog & $\begin{array}{c}\text { Conifer } \\
\text { swamp }\end{array}$ & $\begin{array}{c}\text { Hardwood } \\
\text { swamp }\end{array}$ & $\begin{array}{c}\text { Thicket } \\
\text { swamp }\end{array}$ \\
\hline Conifer swamp & $51.75^{\mathrm{c}}$ & & & \\
Hardwood swamp & $36.57^{\mathrm{c}}$ & $3.21^{\mathrm{b}}$ & & \\
Thicket swamp & $31.45^{\mathrm{c}}$ & $2.34^{\mathrm{a}}$ & $2.77^{\mathrm{a}}$ & \\
Fen & $33.20^{\mathrm{c}}$ & $3.43^{\mathrm{b}}$ & $2.70^{\mathrm{a}}$ & 0.70 \\
\hline
\end{tabular}

\footnotetext{
a $P<0.1$.

${ }^{\mathrm{b}} P<0.05$.

c $P<0.001$.
}

among themselves and from the fens with respect to these water characteristics but there is no clear pattern of statistically significant differences.

Differences between the various wetland types were also examined with multivariate analysis of variance (Table 2). On this basis

TABLE 3. Factor loadings for $1 /$ characteristics of shallow ground water in northern Michigan wetlands. Loadings less than 0.250 have been replaced by zero. Factors were extracted by principal components analysis followed by orthogonal rotation of the axes by varimax

\begin{tabular}{llll}
\hline \hline Characteristic & Factor 1 & Factor 2 & Factor 3 \\
\hline $\mathrm{Ca}$ & 0.977 & 0.0 & 0.0 \\
$\mathrm{Mg}$ & 0.974 & 0.0 & 0.0 \\
$\mathrm{pH}$ & 0.946 & 0.0 & 0.0 \\
$\mathrm{Alkalinity}$ & 0.893 & 0.0 & 0.0 \\
$\mathrm{Si}$ & 0.880 & 0.0 & 0.0 \\
Reactive-P & 0.0 & 0.974 & 0.0 \\
Total-P & 0.0 & 0.960 & 0.0 \\
$\mathrm{NH}_{3}-\mathrm{N}$ & 0.0 & 0.938 & 0.0 \\
$\mathrm{~K}$ & 0.0 & 0.742 & 0.480 \\
$\mathrm{Na}$ & 0.289 & 0.0 & 0.889 \\
$\mathrm{Cl}$ & 0.0 & 0.0 & 0.856 \\
Fraction of the total & & & \\
$\quad$ variance explained & & & \\
by the factor & 0.44 & 0.32 & 0.12 \\
\hline
\end{tabular}



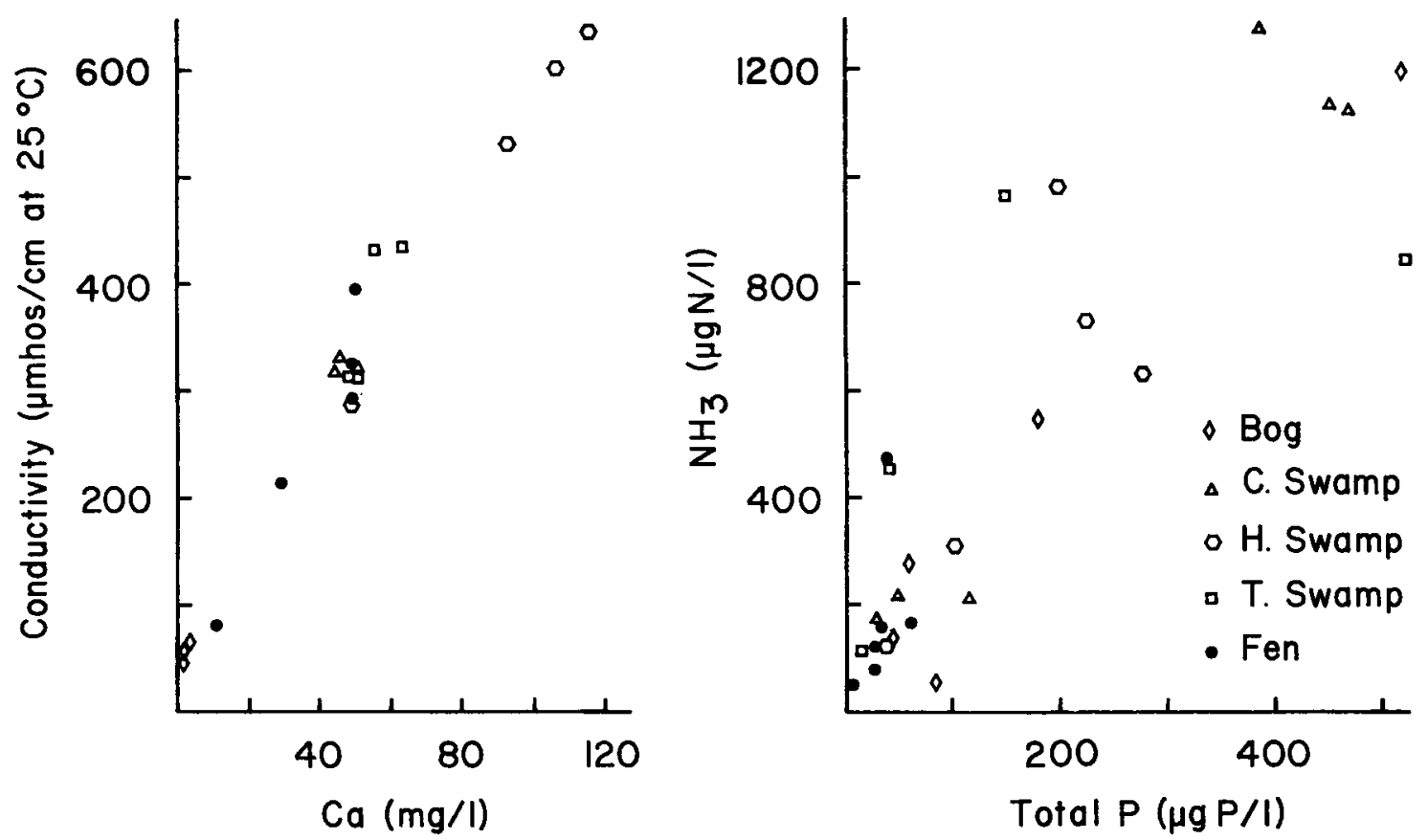

Fig. 1. The relationships between conductivity and calcium, and ammonia-nitrogen and total phosphorus in shallow ground waters of northern Michigan wetlands.

the bogs are sharply differentiated from the three kinds of swamps and fens. Differences between the remaining types in all pair-wise combinations are also statistically significant taken one at a time except for fen-thicket swamp. However, these $F$ values are relatively small and become insignificant when Bonferoni's inequality for multiple comparisons (Fisher and McDonald, 1978) is applied.

Figure 1 shows graphically some of the relationships among wetland water characteristics described in statistical terms in the following paragraphs. Shown are two representative pairs of linearly covarying water characteristics as well as the extent of variation within wetland types and the extent of overlap between wetland types with respect to these characteristics.

Three groups of linearly covarying water characteristics which together account for $82.8 \%$ of the total variance were identified by factor analysis (Table 3). The first group (Factor 1) consists of alkalinity, $\mathrm{Ca}, \mathrm{Mg}, \mathrm{pH}, \mathrm{Si}$, and $\mathrm{Na}$. All except $\mathrm{Na}$ have high factor loadings $>0.85$; the second group includes reactive-P, total-P, $\mathrm{NH}_{3}-\mathrm{N}$, and $\mathrm{K}$, all with high factor loadings $>0.75$; and the third group contains $\mathrm{Na}, \mathrm{Cl}$, and $\mathrm{K}$. In order to determine the approximate factor loadings for conductivity and color, which were not included in the analysis given in Table 3 for reasons previously stated, the factor analysis was repeated using all 15 water characteristics and the untransformed data for each of the individual wells. On this basis five factors were identified. The first three closely resembled those lised in Table 3 . They included the same water characteristics and each water characteristic had a similar factor loading. In addition, conductivity contributed heavily to Factor 1 with a factor loading of 0.975 , whereas color contributed to all three factors with the following factor loadings: Factor $1(-0.511)$; Factor $2(0.297)$; and Factor $3(-0.350)$. The remaining two water characteristics, i.e., $\left(\mathrm{NO}_{2}+\mathrm{NO}_{3}\right)-\mathrm{N}$ and temperature, had factor loadings $<0.250$ on the first three factors.

Figure 2 shows the position of the individual wetland sites with respect to Factors 1 and 2. Here the bogs are clearly separated from the swamps and fens by low Factor 1 scores which fall to the left of the vertical dashed line. The swamps and fens have substantially higher scores and overlap with each other. With respect to Factor 2, all wetland types, including the bogs, overlap. However, the fens can be distinguished because they have consistently low Factor 2 scores which fall below the horizontal dashed line in Fig. 1. Among the bogs, the two sites with relatively high Factor 2 scores are treed bogs and the three sites with lower scores are open bogs. 
Discussion-Individual chemical elements enter the interstitial soil water of the rooting zone in wetlands by three main routes: inflow of telluric waters; decomposition of organic matter; and bulk precipitation. The predominant source depends on the element. Two of the three covarying groups of water characteristics identified by factor analysis (Table 3 ) are clearly related to the primary source of the elements contributing to them. Factor 1 represents water characteristics heavily influenced by telluric water inflow. This factor consists predominantly of $\mathrm{Ca}$ and $\mathrm{Mg}$ and three composite characteristics, namely $\mathrm{pH}$, alkalinity, and conductivity, which reflect the $\mathrm{Ca}$ and $\mathrm{Mg}$ content of the water. Silicon and to a much lesser extent $\mathrm{Na}$ are also associated with this group. Members of this group $(\mathrm{Ca}, \mathrm{Na}, \mathrm{pH}$, alkalinity and conductivity) were also found to covary in interstitial bog and fen waters in the English Lake District (Gorham, 1956) and in Minnesota (Glaser et al., 1981). Consistent with a telluric primary source, $\mathrm{Ca}, \mathrm{Mg}$, and $\mathrm{Na}$ show an annual net loss (stream output exceeds input by bulk precipitation) in each of 20 relatively undisturbed temperate, terrestrial ecosystems examined in detail (Likens et al., 1977). The net loss of $\mathrm{Ca}$ and $\mathrm{Mg}$ is large at two ecosystems which like northern Michigan have carbonaceous sedimentary bedrock. Factor 2 represents elements heavily influenced by accumulation in the vegetation and subsequent decomposition of organic matter. This factor consists predominantly of $\mathrm{N}$ and $\mathrm{P}$ and to a lesser extent $\mathrm{K}$. Consistent with extensive recycling within the ecosystem, $N$ shows a net gain in each temperate ecosystem examined, and $P$ shows a very small net gain in 12 and a very small net loss in four temperate ecosystems (Likens et al., 1977). Moreover, N, P, and $\mathrm{K}$ are held in relatively tight circulation in the Hubbard Brook forest ecosystem (Whittaker et al., 1979). Factor 3 consists primarily of $\mathrm{Na}$ and $\mathrm{Cl}$ and to a much lesser extent $\mathrm{K}$. These elements exist as monovalent ions in interstitial waters and are relatively loosely bound to ion exchange sites in peat (see Hemond, 1977 for a review of cation exchange by peat) with a substantial fraction of the total (dissolved and absorbed) present being dissolved in the interstitial waters. For example, the percentage dissolved in some Irish peat (Gorham, 1967) is: $\mathrm{Cl}(70), \mathrm{Na}(30)$, and $\mathrm{K}(8)$. Consequently these ions move freely through peat and other organic soils and their concentration is determined primarily by hydrological considerations. In addition these elements are influenced by bulk precipitation, which is a major source of $\mathrm{Cl}$ and an important source of
$\mathrm{Na}$ and $\mathrm{K}$ in a variety of ecosystems (Gorham, 1961; Likens et al., 1977; Schlesinger and Hasey, 1980).

The clear separation of the bogs from the swamps and fens in northern Michigan on the basis of telluric (Factor 1) nutrient content (Fig. 1, Table 1) is in agreement with extensive earlier work which has been reviewed by Heinselman (1970). The shallow ground waters of the bogs have very low concentrations of telluric nutrients and are probably weakly minerotrophic. Their $\mathrm{pH}$ and $\mathrm{Ca}$ concentrations are at the high end of the range for ombrotrophic waters in northern Minnesota (Heinselman, 1970), and are in the range for weakly minerotrophic (poor fen) waters in Scandinavia (Sjörs, 1950; Moore and Bellamy, 1974). In addition most bogs contain isolated individuals of swamp birch (Betula pumila), bog rosemary (Andromeda glaucophylla) or tamarack (Larix laricina) (Schwintzer, 1981) which are indicators of weak minerotrophy in northern Minnesota (Heinselman, 1970) and northern Ontario (Sjörs, 1961). However, the region has calcium and magnesium-rich bedrock and glacial till, and hence higher $\mathrm{pH}$ and $\mathrm{Ca}+\mathrm{Mg}$ are to be expected than in regions with noncalcareous parent materials (Gorham, 1961; Sjörs, 1963; Pietsch, 1976). Consequently, possible ombrotrophy cannot be ruled out in the absence of careful hydrologic studies to determine whether telluric water ever penetrates the surface layers of these peatlands.

The clear separation of the bogs from the swamps and fens with respect to apparent color reflects differences in the extent of water movement. The high color in bogs and substantially lower color in swamps and fens indicates that bog waters have little movement while swamp and fen waters have appreciable movement (Glaser et al., 1981).

The finding that bogs cannot be distinguished from swamps and fens with respect to organic (Factor 2) nutrient content (Fig. 1, Table 1) was unexpected. It has frequently been stated that bogs are deficient in some or all of these nutrients or that growth of individual species is limited by one or more of them (Dansereau and Segadas-Vianna, 1952; Watt and Heinselman, 1965; Moizuk and Livingston, 1966; Goodman and Perkins, 1968; Small, 1972; Moore and Bellamy, 1974; and others). In the past $\mathrm{N}, \mathrm{P}$, and $\mathrm{K}$ have often not been included in studies of nutrient levels in shallow ground waters in wetlands because of difficulties in measurement. Thus there is little direct information about their relative concentrations in various wetlands. Concentrations of $\mathrm{NH}_{3}-\mathrm{N}$ and $\mathrm{K}$ comparable to those in northern Michigan 


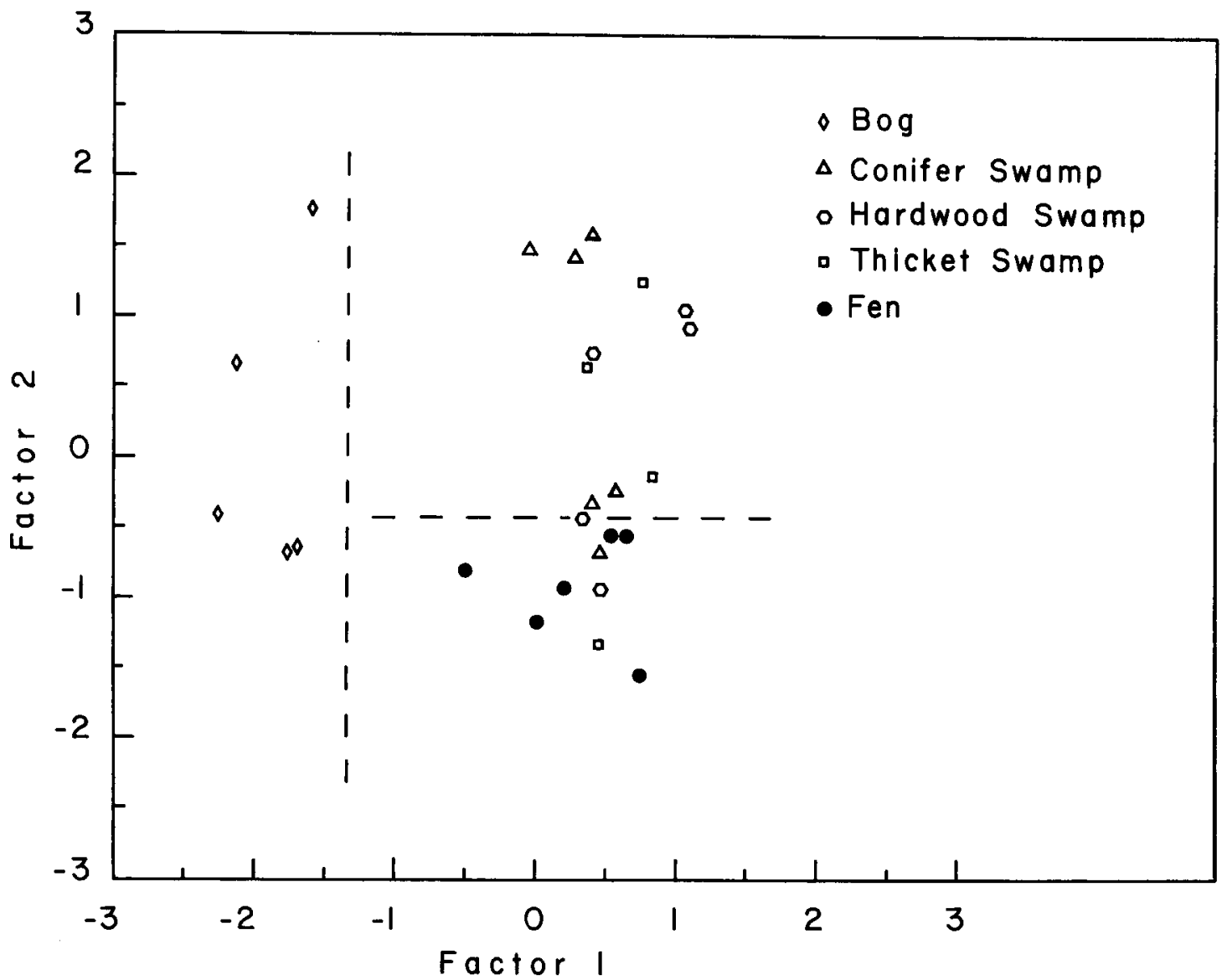

Fig. 2. Ordination of shallow ground waters of northern Michigan wetlands with factor analysis using factor scores as coordinates. Factor 1 represents telluric nutrients and Factor 2 organically derived nutrients. See Table 3 ior factor loadings of individual water charcteristics.

TABLE 4. Characteristics of shallow ground waters in northern Michigan, northern Wisconsin, and northern Minnesota wetlands. Values are from the following sources: MI (present study), WI (Wilde and Randall, 195I), and $M N$ (Heinselman, 1970)

\begin{tabular}{|c|c|c|c|c|c|}
\hline & \multirow[b]{2}{*}{ Description } & \multicolumn{4}{|c|}{ Range of water characteristics } \\
\hline & & $\mathrm{pH}$ & $\begin{array}{l}\text { Conductivity } \\
\mu \text { mhos } / \mathrm{cm} \\
\text { at } 25 \mathrm{C}\end{array}$ & $\begin{array}{l}\text { Alkalinity } \\
\mathrm{mg} / \mathrm{l} \text { as } \mathrm{CaCO}_{3}\end{array}$ & $\begin{array}{c}\mathrm{Ca} \\
\mathrm{mg} / 1\end{array}$ \\
\hline \multicolumn{6}{|l|}{ Bogs } \\
\hline MI & Depression or valley bogs & $3.8-4.3$ & $48-66$ & None & $1.2-3.7$ \\
\hline WI & $\begin{array}{l}\text { "Moss peat: black spruce- } \\
\text { tamarack muskeg" }\end{array}$ & $3.5-4.2$ & $50-61$ & None & \\
\hline $\mathrm{MN}$ & Semiraised or raised bogs & $3.2-3.8$ & $35-78^{\mathrm{a}}$ & None & $0.6-3.5$ \\
\hline \multicolumn{6}{|c|}{ SWAMPS } \\
\hline MI & White cedar swamp & $6.7-7.4$ & $249-332$ & $129-197$ & $28-50$ \\
\hline WI & White cedar swamp & $6.2-7.3$ & $75-240$ & $24-134$ & \\
\hline $\mathrm{MN}$ & White cedar swamp & $6.0-6.5$ & $84-119^{a}$ & & $15-28$ \\
\hline \multicolumn{6}{|l|}{ FENS } \\
\hline MI & Open fen & $5.7-7.0$ & $83-397$ & $29-228$ & $11-75$ \\
\hline WI & $\begin{array}{l}\text { "Sedge peat: marsh" } \\
\text { Part of string bog and patterned } \\
\text { fen or forest island and }\end{array}$ & $6.4-7.0$ & $380-650$ & $144-332$ & \\
\hline $\mathrm{MN}$ & fen complexes & $5.0-6.6$ & $31-67^{\mathrm{a}}$ & & $4-10$ \\
\hline
\end{tabular}

\footnotetext{
a Conductivity at $20 \mathrm{C}$.
} 
bogs have also been found in a Massachusetts bog (Hemond, 1980) but there is no information on $P$ concentrations. Verry (1975) found annual yields of $\mathrm{N}, \mathrm{P}$, and $\mathrm{K}$ from perched Minnesota bog watersheds were similar to other forested areas at a similar latitude in North America. In addition, concentrations of $\mathrm{NH}_{3}-\mathrm{N}, \mathrm{PO}_{4}-\mathrm{P}$, and soluble $\mathrm{K}$ are higher in the peat of South German bogs than fens (Waughman, 1980). Thus it appears that bogs have at least modest concentrations of these nutrients. Presence of modest concentrations of $\mathrm{N}, \mathrm{P}$, and $\mathrm{K}$ in shallow ground waters of bogs is not necessarily incompatible with observations that the annual supply of these elements is limiting. A variety of factors related to very limited water movement past the roots (Sparling, 1966; Moore and Bellamy, 1974; Gosselink and Turner, 1978) may limit uptake of $\mathrm{N}, \mathrm{P}$, and $\mathrm{K}$ by plants in bogs. These include local depletion of nutrients in the vicinity of the roots and accumulation of phytotoxic byproducts of anerobic metabolism. Nevertheless, the unexpectedly high $\mathbf{N}$, $P$, and $K$ concentrations observed in bogs deserve further investigation.

The shallow ground waters of the swamps and fens are moderately to strongly minerotrophic and are only partially differentiated among themselves with respect to telluric and organic nutrient contents (Fig. 1, Table 1). It should be noted, however, that the fens have consistently low $\mathrm{N}$ and $\mathrm{P}$ concentrations (Table 1) and Factor 2 scores (Fig. 1). In this regard it is interesting that strong development of symbiotic nitrogen-fixing species was found only in fens in northern Michigan (Schwintzer, 1981) and nitrogen fixation by heterotrophic bacteria in the peat was greatest at moderately to strongly minerotrophic sites in North America and Europe (Waughman and Bellmay, 1980). Multivariate analysis of variance (Table 2) indicates considerable similarity between the thicket swamps and fens. This may be due to similar hydrological conditions. All four thicket swamps and five of the six fens were located adjacent to a stream or lake.

Failure to completely separate the vegetationally very distinct swamps and fens (Schwintzer, 1981) on the basis of their nutrient content indicates that one or more additional factors are of major importance in determining their vegetation. These may include water level (moisture-aeration regime), water movement, and past history of the site (Gorham, 1950; Gorham and Pearsall, 1956; Moore and Bellamy, 1974). Moisture-aeration regime is likely to be of major importance. It is important in regulating growth and survival of individual wetland species (Moore and Bellamy, 1974;
Armstrong, 1975) and even small changes in water level of $10 \mathrm{~cm}$ or less during the growing season can have measurable effects on growth and survival of woody species (Heinselman, 1963; Schwintzer, 1978a). Unfortunately, the available information does not permit evaluation of the role of moisture-aeration regime and water movement. The history of the various sites is also largely unknown although the general history of the wetlands of the region is known (Schwintzer, 1981). All open bogs are on sites known to have burned between 60 and 80 years ago and probably would be treed bogs in the absence of fire (Gates, 1942).

The same general relationships between wetland vegetation and chemistry of shallow ground waters observed in northern Michigan probably also exist in other nearby parts of the Laurentian Mixed Forest ecoregion. Only limited comparisons are possible, but the available data for interstitial waters in wetlands in northern Wisconsin and northern Minnesota indicates that they are similar to those in northern Michigan (Table 4) at least with respect to degree of minerotrophy.

\section{LITERATURE CITED}

Alfred, S. D., A. G. Hyde, ANd R. L. Larson. 1973. Soil survey of Emmet County, Michigan, U.S. Dep. Agric., Soil Cons. Serv. Maps 1-45.

American Public Health Association. 1971. Standard methods for the examination of water and wastewaters. 13th ed. APHA, New York.

Armstrong, W. 1975. Water logged soils. In J. R. Etherington [ed.], Environment and plant ecology, p. 181218. John Wiley and Sons, New York.

Bailey, R. G. 1976. Ecoregions of the United States. Map. U.S. For. Serv., Ogden, Utah.

CurTis, J. T. 1959. The vegetation of Wisconsin. University of Wisconsin Press, Madison.

Dansereau, P., and F. Segadas-Vianna. 1952. Ecological study of the peat bogs of Eastern North America. I. Structure and evolution of vegetation. Can. J. Bot. 30: 490-520.

Dixon, W. J., AND M. B. Brown. 1977. BMDP-77. Biomedical computer programs P-series. University of California Press, Berkeley.

Dorr, J. A. JR., AND D. F. Eschman. 1970. Geology of Michigan. University of Michigan Press, Ann Arbor.

DuRietz, E. G. 1954. Die Mineralboden-wasserzeigergrenze als Grundlage einer natürlichen Zweigliederung der Nord-und Mitteleuropäischen Moore. Vegetatio 5/6: 571-585.

Fernald, M. L. 1950. Gray's manual of botany. 8th ed. American Book Co., New York.

Fisher, L., AND J. MCDonald. 1978. Fixed effects analysis of variance. Academic Press, New York.

Gates, F. C. 1942. The bogs of northern Lower Michigan. Ecol. Monogr. 12: 213-254.

Glaser, P. H., G. A. Wheeler, E. Gorham and H. E. WRIGHT, JR. 1981. The patterned mires of the Red 
Lake Peatland, northern Minnesota: Vegetation, water chemistry and landforms. J. Ecology 69: 575-600.

Goodman, G. T., and D. F. Perkins. 1968. The role of mineral nutrients in Eriophorum communities. IV. Potassium is a limiting factor in an E. vaginatum community. J. Ecology 56: 685-696.

Gorham, E. 1950. Variation in some chemical conditions along the borders of a Carex lasiocarpa fen community. Oikos 2: 217-240.

_. 1956. The ionic composition of some bog and fen waters in the English Lake District. J. Ecology 44: $142-152$.

- - 1961. Factors influencing supply of major ions to inland waters with special reference to the atmosphere. Geol. Soc. Amer. Bull. 72: 795-840.

. 1967. Some chemical aspects of wetland ecology. Annual Muskeg Res. Conf. Proc. 12: 20-38.

$\longrightarrow$, and W. H. Pearsall. 1956. Acidity, specific conductivity and calcium content of some bog and fen waters in northern Britain. J. Ecology 44: 129 141 .

Gosselink, J. G. And R. E. Turner. 1978. The role of hydrology in freshwater wetland ecosystems. In R. E. Good, D. F. Whigham, and R. L. Simpson [eds.], Freshwater wetlands, p. 63-78. Academic Press, New York.

Heinselman, M. L. 1963. Forest sites, bog processes, and peatland types in the Glacial Lake Agassiz Region, Minnesota. Ecol. Monogr. 33: 327-374.

- 1970. Landscape evolution, peatland types, and the environment of the Lake Agassiz Peatlands Natural Area, Minnesota. Ecol. Monogr. 40: 235-261.

HEMOND, H. F. 1977. Biogeochemistry of a New England Sphagnum bog. Dissertation. Massachusetts Institute of Technology, Cambridge, Massachusetts. . 1980. Biogeochemistry of Thoreau's Bog, Concord, Massachusetts. Ecol. Monogr. 50: 507-526.

Jeglum, J. K., A. N. Boissonneau, ANd V. F. Haavisto. 1974. Towards a wetland classification for Ontario. Can. For. Serv. Dept. Environ. Inf. Rep. O-X215.

KaPP, R. O. 1978. Presettlement forests of the Pine River watershed (Central Michigan) based on original land survey records. Mich. Bot. 17: 3-15.

Likens, G. E., F. H. Bormann, R. S. Pierce, J. S. EATON, AND N. M. Johnson. 1977. Biogeochemistry of a forested ecosystem. Springer-Verlag, New York.

Menzel, D. W., ANd N. Corwin. 1965. The measurement of total phosphorus in sea water based on the liberation of the organically bound fraction by persulfate oxidation. Limnol. Oceanogr. 10: 280-282.

Moizuk, G. A., AND R. B. Livingston. 1966. Ecology of red maple (Acer rubrum L.) in a Massachusetts upland bog. Ecology 47: 942-950.

Moore, P. D., And D. J. Bellamy. 1974. Peatlands. Springer-Verlag, New York.

Perkin-Elmer. 1973. Analytical methods for atomic absorption spectrophotometry. Perkin-Elmer, Norwalk, Connecticut.

PietsCH, W. 1976. Vegetationsentwicklung und wasserchemische Faktoren in Moorgewässern verschiedener Naturschutzgebiete der DDR. Arch. Naturschutz Landschaftsforsch. 16: 1-43.

Richardson, C. J., D. L. Tilton, J. A. Kadlec, J. P.
M. Chamie, and W. A. Wentz. 1978. Nutrient dynamics of northern wetland ecosystems. In R. E. Good, D. F. Whigham and R. L. Simpson [eds.], Freshwater wetlands, p. 217-241. Academic Press, New York.

Schlesinger, W. H., AND M. M. Hasey. 1980. The nutrient content of precipitation, dry fallout, and intercepted aerosols in the chaparral of Southern California. Amer. Midl. Nat. 103: 114-122.

Schwintzer, C. R. 1978a. Nutrient and water levels in a small Michigan bog with high tree mortality. Amer. Midl. Nat. 100: 441-451.

- 1978b. Vegetation and nutrient status of northern Michigan fens. Can. J. Bot. 56: 3044-305l.

- 1979 . Vegetation changes following a water level rise and tree mortality in a Michigan bog. Mich. Bot. 18: $91-98$.

- 1981. Vegetation and nutrient status of northern Michigan bogs and conifer swamps with a comparison to fens. Can. J. Bot. 59: 842-853.

SJörs, H. 1950 . On the relation between vegetation and electrolytes in north Swedish mire waters. Oikos 2: 241-258.

- 1961. Forest and peatland at Hawley Lake, Northern Ontario. Bull. Natl. Museum Can. 171: 131 .

. 1963. Bogs and fens on Attawapiskat River, Northern Ontario. Bull. Natl. Mus. Can. 186: 45-133.

SMALL, E. 1972. Ecological significance of four critical elements in plants of raised Sphagnum peat bogs. Ecology 53: 498-503.

Sokal, R. R., AND F. J. RohlF. 1969. Biometry. W. H. Freeman and Company, San Francisco.

Sparling, J. H. 1966. Studies on the relationship between water movement and water chemistry of mires. Can. J. Bot. 44: 747-758.

TeChnicon. 1973. Industrial methods. Technicon Instruments Corporation, Tarrytown, New York.

U.S. DEPARTMENT OF Commerce, NOAA-National OCEAN SuRvey. Great Lakes water levels, C3314. Rockville, Maryland. Published yearly.

U.S. Department of Interior, Geological Survey. Water Resources Data for Michigan, Part 1. Surface Water Records. Published yearly 1961-1977.

VERRY, E. S. 1975. Streamflow chemistry and nutrient yields from upland-peatland watersheds in Minnesota. Ecology 56: 1149-1157.

Watt, R. F., AND M. L. Heinselman. 1965. Foliar nitrogen and phosphorus level related to site quality in a northern Minnesota spruce bog. Ecology 46: 357361 .

Waughman, G. J. 1980. Chemical aspects of the ecology of some South German peatlands. J. Ecol. 68: 1025-1046.

- AND D. J. Bellamy. 1980. Nitrogen fixation and the nitrogen balance in peatland ecosystems. Ecology 61: 1185-1198.

WhitTaker, R. H., G. E. Likens, F. H. Bormann, J. S. Eaton, And T. G. Siccama. 1979. The Hubbard Brook ecolosystem study: forest nutrient cycling and element behavior. Ecology 60: 203-220.

Wilde, S. A., AND G. W. Randall. 1951. Chemical characteristics of ground water in forest and marsh soils of Wisconsin. Trans. Wis. Acad. Sci. Arts Lett. 40: $251-259$. 